\title{
Concordance in global office market cycles
}

Article

Accepted Version

Stevenson, S., Akimov, A., Hutson, E. and Krystalogianni, A. (2014) Concordance in global office market cycles. Regional Studies, 48 (3). pp. 456-470. ISSN 1360-0591 doi: https://doi.org/10.1080/00343404.2013.799763 (special Issue: Finance, business property and urban and regional development) Available at https://centaur.reading.ac.uk/35448/

It is advisable to refer to the publisher's version if you intend to cite from the work. See Guidance on citing.

Published version at: http://www.tandfonline.com/doi/full/10.1080/00343404.2013.799763\#.UpxXVcTlbMg To link to this article DOI: http://dx.doi.org/10.1080/00343404.2013.799763

Publisher: Routledge

All outputs in CentAUR are protected by Intellectual Property Rights law, including copyright law. Copyright and IPR is retained by the creators or other copyright holders. Terms and conditions for use of this material are defined in the End User Agreement.

\section{www.reading.ac.uk/centaur}

\section{CentAUR}

Central Archive at the University of Reading 
Reading's research outputs online 


\section{Concordance in global office Market Cycles}

Article

Accepted Version

Stevenson, S., Akimov, A., Hutson, E. and Krystalogianni , A. (2014) Concordance in global office Market Cycles. Regional Studies, 48 (3). pp. 456-470. ISSN 1360-0591 doi:

10.1080/00343404.2013.799763 Available at http://centaur.reading.ac.uk/40901/

It is advisable to refer to the publisher's version if you intend to cite from the work.

Published version at: http://dx.doi.org/10.1080/00343404.2013.799763

To link to this article DOI: http://dx.doi.org/10.1080/00343404.2013.799763

Publisher: Routledge

All outputs in CentAUR are protected by Intellectual Property Rights law, including copyright law. Copyright and IPR is retained by the creators or other copyright holders. Terms and conditions for use of this material are defined in the End User Agreement.

www.reading.ac.uk/centaur

\section{CentAUR}

Central Archive at the University of Reading 
Reading's research outputs online 


\title{
Concordance in Global Office Market Cycles
}

\author{
Accepted for publication in Regional Studies
}

Simon Stevenson (University of Reading), Alexey

Akimov(Lancaster University), Elaine Hutson (Monash

University) \& Alexandra Krystalogianni (Allianz Real Estate) 


\title{
Concordance in Global Office Market Cycles
}

\author{
Simon Stevenson, University of Reading \\ Corresponding Author: School of Real Estate \& Planning, Henley Business School, University of \\ Reading, Whiteknights, Reading, RG6 6AW, United Kingdom. Tel: +44-118-378-4008, \\ e-mail: s.a.stevenson@ reading.ac.uk \\ Alexey Akimov, University of Lancaster \\ Elaine Hutson, Monash University \\ $\&$ \\ Alexandra Krystalogianni, Allianz Real Estate
}

\begin{abstract}
A large proportion of international real estate investment is concentrated in the office markets of the world's largest cities. However, many of these global cities are also key financial services centres, highlighting the possibility of reduced economic diversification from an investor's perspective. This paper assesses the degree of synchronization in cycles across twenty of the world's largest office markets, finding evidence of significant concordance across a large number of markets. The results highlight the problems associated with commonalities in the underlying economic bases of the markets. The concentration of investment also raises the possibility of common flow of funds effects that may further reduce diversification opportunities.
\end{abstract}




\section{Concordance in Global Office Market Cycles}

\section{1: Introduction}

The last decade has seen a large increase in cross-border investment in real estate. As recently as the mid-1990s, relatively little international investment occurred in the property sector, particularly in comparison to capital market assets such as equities and bonds ${ }^{1}$. To illustrate the dearth of international investment, Worzala (1994) found that 55\% of institutional real estate investors held no overseas assets ${ }^{2}$. However, since the turn of the millennium, cross-border investment in real estate has risen at a remarkable rate. In Europe alone, annual cross-border investment increased from less than $€ 25 \mathrm{bn}$ in 2000 to over $€ 150 \mathrm{bn}$ in 2006 and 2007 (Jones Lang LaSalle, 2007, 2008). While the broad principles of international diversification can be seen to lend justification to this broadening of the asset base, the case in real estate warrants a closer examination.

The underlying rationale behind international diversification is that as asset performance is interconnected with economic fundamentals, if an investor diversifies globally they are subject to fewer common underlying driving forces. This should therefore feed through to reduced correlations across assets and markets and lead to increased diversification benefits. Indeed, in a real estate context the rationale is particularly attractive. As a privately traded asset, real estate is more closely tied with underlying fundamentals than capital market assets such as equities, and a large literature has clearly illustrated the importance of economic fundamentals in the determination of both rental and capital values (e.g., Guissani et al., 1993, D’Arcy et al., 1997, Quan \& Titman, 1999, and De Wit \& Van Dijk, 2003). One would therefore expect that the benefits of diversifying internationally would be enhanced in a real estate context. Indeed, some empirical work would seem to imply that this is the case. Conner \& Liang (2005), for example, show that the average correlation between the US stock market and foreign markets has increased and has been consistently above 0.70 since 1988 . In contrast, the corresponding average correlation in terms of US GDP is only 0.19 . This would imply that a real estate fund manager would observe enhanced diversification benefits in a global setting in comparison to a corresponding equity manager. 
However, this initial analysis fails to take into account one key element, namely that global real estate investment is not evenly distributed. Rather, it is highly concentrated - not only in a small number of countries but also in a limited range of metropolitan areas within those countries. In particular, those markets in which investment is concentrated are largely the major global financial centres. This paper considers the degree to which the office markets of global cities display evidence of synchronisation in their cycles. The empirical analysis considers 20 of the world's largest office markets and is based upon the concordance measure proposed by Harding \& Pagan (2006). The results reveal that many large office markets are indeed synchronised to a statistically significant degree. There is, however, evidence of segmentation with respect to continental European markets, and to some extent with AsiaPacific markets. The findings broadly show that many of the primary destinations for real estate investment are synchronised, thereby implying reduced international diversification benefits. This applies not only in the context of real estate-only portfolios; multi-asset class portfolio managers are also potentially affected due to the linkages between the global office markets and the broad capital markets. Such funds managers may not be reaping the diversification benefits that are commonly seen as being one of the key advantages of real estate as an asset class. The remainder of the paper is structured as follows. Section 2 discusses in more depth the relevant literature, Section 3 details the data used in the empirical analysis which in turn is presented in Section 4. The final section provides concluding comments.

\section{2: Literature Review}

Despite the large amount of literature devoted to real estate portfolio management, remarkably little has concentrated on cross-border investment. This lack of research is in part due to a combination of data limitations and the fact that until the last decade the vast majority of real estate investment was domestic in nature. The relative lack of long-term data has meant that the majority of the empirical work to have considered real estate in an international context has in fact concentrated on a small number of markets, particularly the US and UK and to some degree Japan ${ }^{3}$. Furthermore, many of these papers have focused upon the issue of foreign exchange exposure ${ }^{4}$. In fact, very few papers have 
considered the role that international real estate can play in a portfolio context. Chua (1999) considers the portfolio diversification benefits of real estate in a mixed asset context for France, Germany, Japan, the UK and the USA. The results support the view that overseas real estate, in addition to domestic, plays a role in an optimal portfolio. Hoesli et al. (2004) consider seven markets (US, UK, France, Netherlands, Sweden, Switzerland and Australia) and provide supporting evidence to Chua (1999). In each case, not only does domestic real estate obtain an optimal allocation, but so does international real estate. Using a different methodological approach, Liow (2010) also provides empirical evidence on the diversification potential available internationally. The author uses the Gregory \& Hansen (1996) test for cointegration in the presence of structural breaks. In the majority of the systems there is no evidence of cointegration, implying long-term diversification benefits. However, this finding is weakest when considering the US, UK and Australia. This is a broadly consistently finding in terms of Myer et al. (1997) who find evidence of cointegration, and therefore a common long-term trend in the case of the US, UK and Canada.

However, the conventional portfolio papers that have looked at cross-border investment have largely utilised data at a national level. This raises two issues. Firstly, due to the heterogeneous nature of the asset, it is well established that it is very difficult for a real estate fund manager to naively diversify their portfolio to the extent that they can replicate the performance of national indices ${ }^{5}$. Secondly, global investment in real estate is extremely concentrated in a small number of key centres. Whilst Webb \& O'Keefe (2002) note that there are only fourteen countries globally that can support real estate as a separate asset class, the level of concentration is effectively at a metropolitan level. To illustrate this, Jones Lang LaSalle (2007, 2008, 2009a, 2009b, 2010) estimate that within a European context, the UK is consistently the largest single destination for cross-border investment in property. In $200545 \%$ of all cross-border investment was into the UK, although this declined to $25 \%$ in 2008 . Furthermore, this investment itself is further concentrated. According to Jones Lang LaSalle, in the first nine months of $200853 \%$ of overseas purchases in UK real estate were in the London office market, and Lizieri \&Kutsch (2006) note that foreign ownership of office properties in the City of London exceeds 45\%. Lizieri (2009b) shows that over 40\% of major office deals completed in 2007 
and 2008 were concentrated in just five metropolitan areas: New York, London, Tokyo, Paris and Singapore. This has wide-ranging implications. Firstly, it highlights the limitations in relying on national data to effectively consider the diversification potential of global real estate. Secondly, the markets in which the investment is concentrated have similar economic bases; specifically, they are the major global financial services centres. Indeed, to further illustrate this point, Lizieri (2009b) notes that $72 \%$ of all office deals took place in cities ranked in the Z/Yen Global Financial Centers Index.

It is evident that this concentration of investment in global financial centres has a number of implications for real estate investors. The economic geography literature has long been concerned with the concept of world cities, with a large literature considering the growth and development of a world city network. An important element of this literature many of the global cities share a common feature in their acting a major financial services centres. This means that global real estate investment is concentrated in cities around the world that have common economic driving forces. The importance of economic concentration has been clearly demonstrated in a real estate context, and this implies that such a portfolio approach may be economically undiversified (e.g. Goeztmann \& Wachter, 1995). This has potential implications for mixed-asset fund managers. The concentration of property investment in markets that have strong linkages with capital market assets could lead to a reduction in the diversification benefits a multi-asset manager obtains. This consequence arises from two issues. Firstly, that an investment strategy that is effectively economically undiversified may lead to a foregoing of diversification benefits. Secondly, the linkages between the global city office markets and the capital markets may result in a strategy that does not yield the diversification benefits associated with property as an asset class.

It is interesting to consider the broader implications of the majority of international investment being concentrated in financial centres. During the course of the last thirty years, a large literature has developed in economic geography relating to the concept of world cities and internationalisation. A key issue in this literature is that many of the world's global cities are financial services centres. Kindelberger (1974) links the role of global cities with their function as financial services centres, and 
Friedman (1986, 1995) argues that such metropolitan areas act as 'control centres' for capital accumulation. Sassen $(1991,1994)$ also highlights the importance of financial services in her analysis of London, New York and Tokyo, although she adopts a slightly different emphasis in that her analysis focuses upon the servicing of global capital rather than its management. Amin \& Thrift (1997) cite key areas with respect to globalisation, the first being globalisation of money and capital. A number of papers have also considered the importance of skilled migration across world cities and the importance in terms of connectivity that this provides and the role that a global network of corporate offices play in facilitating this (e.g. Frideman \& Wolf, 1982; Sassen 1988, 1994; Beaverstock, 1994; Findlay et al., 1996). Taylor et al. (2002b) describes their role as providing 'a skeletal structure for globalisation'. Beaverstock \& Boardwell (2000) note that professional skilled migration increased since the 1980s, and highlight the importance of global financial services firms and their role in the interlinkages between key global centres ${ }^{6}$.

The role of real estate in the context of global cities is an under-researched area in both the economic geography and real estate literatures ${ }^{7}$. The economic base dominated by financial services has the effect that such cities will have a large number of property tenants - not only in the same industry, but in many cases they will be the same firms. Lizieri et al. (2000) highlight the importance of financial services tenants in the context of London; by $199750 \%$ of City of London office space was occupied by the financial services sector. If this is extended to include all FIRE (Finance, Insurance and Real Estate) firms and other business services, $87 \%$ of City occupation is included. Lizieri et al. (2000) also note that over one-third of City offices were occupied by foreign tenants. However, what is important is not only that real estate investment is concentrated in such markets, but that global financial activity is concentrated in the same markets. Beaverstock et al. (2000) note that London's corporate connections in the banking and finance industry is concentrated in seven centres (New York, Hong Kong, Singapore, Tokyo, Frankfurt, Paris and Zurich). Beaverstock \& Smith (1996) highlight this in the context of employment in the investment banking sector, with a third of London's employment flows heading to New York and nearly 75\% to just 6 centres: New York, Tokyo, Hong Kong, Paris, Sydney and Madrid. In addition, research by Deutsche Bank (2010) reveals that more than $75 \%$ of all 
global investment banking revenue occurs in the US and EU, and the main equity markets of the US, EU, Japan, Singapore and Hong Kong still comprise $79 \%$ of equity trading. Furthermore, $70 \%$ of all fixed income securities are registered in the EU and US and over half of global foreign exchange trading takes place in the UK and US.

The influence of the capital markets may be enhanced due to their role as a key demand factor in the office sector. The evidence of increased integration in the capital markets has the implication of further increasing the risk that real estate investors are potentially open to $^{8}$.The integration of global financial markets may also lead to increasing convergence in the corporate performance of tenants in such markets. Dehesh \& Pugh $(1999,2000)$ note that changes in the global economic system have amongst other things led to a process of deregulation, one consequence of which has been increased capital flows. They argue that during periods of domestic economic stability, property cycles are largely endogenous and primarily driven by disequilibrium in the sector. However, in times of economic instability they are exogenous. As global integration increases so does the risk of foreign shocks impacting upon real estate. It could also be argued that the deregulation that occurred in many markets in the financial services industry from the late 1970s onwards contributed to this exposure by aiding in the development and growth of the global financial services firms.

The importance of the economic base of the specific metropolitan area has been long established in the real estate literature. The role of economic driving forces in the determination of property returns is clearly established in a domestic localised context in the modelling literature (e.g. Wheaton, 1999). This influence has also been illustrated in an international framework. Guissani et al. (1993) and D'Arcy et al. (1997) consider European markets, and show the importance of GDP in the determination of rental values. In a global context, Quan \& Titman (1999) consider 17 global markets, and find that not only rents but also capital values are significantly related to economic variables such as GDP. Case et al. (1999) and De Wit \& Van Dijk (2003) specifically consider metropolitan markets, and both papers confirm the importance of economic variables such as GDP or GNP. The implications of such findings in a portfolio context are widespread. The importance of economic 
performance means that markets with similar underlying economic bases, and therefore similar systematic effects, may behave in a similar manner. This has the implication that simple geographic diversification - at both national and international levels - may not guarantee diversification. A number of domestic studies in the UK and US have considered the portfolio implications, and as an extension have sought to group together markets with a similar economic base (e.g. Miles \& McCue, 1982; Goeztmann \& Wachter, 1995; Hoesli et al. 1997; Hamelink et al. 2000; and Jackson, 2002). In a global setting, evidence has been more limited. Goeztmann \& Wachter (2001) undertake a similar analysis to that contained in the domestic study of Goeztmann \& Wachter (1995). However, the global analysis is constrained due to its concentration on the crash of the late 1980s and early 1990s; their findings of strong international and continental affects must be viewed in this context.

The few empirical papers that have considered the implications of such effects from the perspective of a portfolio manager have reported largely consistent findings. Jackson et al. (2008) and Brooks \& Tsolacos (2008) report evidence of cointegration with respect to the London and New York office markets, and in Brooks \& Tsolacos (2008), Tokyo as well. A recent paper by Lizieri (2009b) analyses 28 global cities using principal components analysis. The results provide evidence of a global factor, with the first component explaining $38 \%$ of the variation in the rental data analysed, and all but eight of the markets having loadings in excess of 0.50 .

The combination of both common economic driving forces and possible flow of funds effects may have the effect of constraining the diversification opportunities available. The final implication relates to the role of real estate in a mixed-asset portfolio. If the major global office markets are dominated by financial services firms as occupants, then this could result in (or contribute to) a strong correlation between real estate assets and financial assets. Froland et al. (1986) was one of the earliest papers to highlight the increased link between real estate markets (such as New York) and the stock market, and therefore reduced diversification in a multi-asset context. More recently, Stevenson \& Young (2011) highlight the relation between the financial markets and the London office markets, in a vector autoregression framework. A paper by Heathcote \& Perri (2004), which considers financial and 
economic integration, is also of interest in this regard. They note that whilst real economic integration has weakened in recent decades, financial integration has strengthened. Such findings may initially appear to be beneficial in terms of the diversification potential inherent in real estate. However, the linkages between financial services and the capital markets and the primary global office market means that investors in such markets do not necessarily benefit from reduced real economic integration. In addition, Heathcote \& Perri (2004) argue that through increased capital flows, financial globalisation reduces correlations in GDP, whilst at the same time financial globalisation is endogenous to real shocks.

\section{3: Data and Methodological Framework}

The data used in this study consists of rental and capital value figures for twenty of the largest office markets globally. The markets include a selection of key centres in Europe, the United States and Asia-Pacific. In Europe the markets examined are: Paris, Frankfurt, Milan, Amsterdam, Barcelona, Madrid, City of London, West End of London, and Edinburgh. For the United States the following major cities are included in the analysis: Boston, Chicago, Los Angeles, New York, San Francisco, Seattle, and Washington D.C. Lastly, the following cities are included from the Asia-Pacific region: Hong Kong, Singapore, Tokyo and Sydney. As Table 1 illustrates, seven of the cities selected are in the 2010 GFCI 8 top ten ranked global financial services centres. In many cases, the choice of cities analysed was dictated to by the availability of data. The data are quarterly and extends from 1990 to 2009. Unavailability of data for markets such as Geneva, Zurich, Toronto and the Chinese markets necessitated their exclusion from the sample. However, the final sample does include the majority of the world's major global financial services centres.

There is a fundamental difficulty in the analysis of direct commercial property performance in a global context caused by the lack of long-term data series and the lack of a consistent global property data set. We have compiled a database of capital value and rental indexes for offices from various data providers in order to make a global analysis possible. Our data sources are CBRE for Europe, JLL for the Asia Pacific, and PPR for the US. All variables are in local currency. The differences in 
definitions of rents and capital values reflect local market practices. The rent and capital value data for Europe and Asia Pacific are for prime office property, while for the US they reflect average transacted rent and capital values. In many of the European and Asian property markets prime rents and capital values are the only data available over more than the last ten years. Prime rents are recorded as at the end of each quarter, and are based on an opinion of the rent that would normally be achieved for high quality space in the CBD based on market transactions in the absence of special circumstances. Capital values data in Asia Pacific are based on transactions observed for prime office space in the CBD in each time period. Capital values for Europe are derived from prime rents and prime initial yields observed on transactions. The US capital values, from PPR, are derived from Net Operating Income (NOI) and cap rates.

Table 2 provides details of the average returns of both the rental and capital value series. These summary statistics are provided in both nominal and real terms. The rationale behind considering both nominal and real returns is that whilst real returns may provide insights into underlying fundamentals, nominal returns are what investors actually obtain. It is quite clear that (particularly in real terms) the markets in general have not delivered impressive performance during the last two decades. With respect to rents, only Amsterdam, New York, San Francisco and Hong Kong have seen positive average real returns. In the case of capital values, only six cities have seen positive average real returns: Amsterdam, London's West End, Edinburgh, Hong Kong, Tokyo and Sydney. These results are in part due to the extreme falls observed since 2007. This also explains why even in nominal terms some markets have seen negative average figures. For example, the City of London market saw nominal capital values fall by $55 \%$ in the two years to June 2009 .

The methodology that we adopt in this paper, however, is not biased by extreme movements, as it uses state variables that merely consider whether a market is in a state of expansion or contraction. The methodological approach is based upon a measurement of concordance that has been empirically used in the context of business cycles. Harding and Pagan (2002) propose a non-parametric approach to estimating the level of concordance between two growth rate series. The growth rates are expressed 
as two binary random variables, $S_{i t}$ and $S_{j t}$, which are the state variables for cycles for markets $i$ and $j$. The state variables are defined as dummy variables equalling unity when the cycle is on an upward trend, so in the case of the real estate data used in this study a positive period return, and zero otherwise. The average values of the state variables for each market are displayed in Table 3 . Using these two state variables, the index of concordance between two cities provides the information about the proportion of time two cycles spend in the same phase. The simple index can be calculated as follows:

$$
\mathrm{IC}=\mathrm{T}^{-1} \sum_{\mathrm{t}=1}^{\mathrm{T}}\left\{\mathrm{S}_{\mathrm{jt}} \mathrm{S}_{\mathrm{it}}+\left(1-\mathrm{S}_{\mathrm{jt}}\right)\left(1-\mathrm{S}_{\mathrm{it}}\right)\right\}
$$

This statistic can also be adapted in what has been referred to as the Mean Corrected Index of Concordance. This adaptation, proposed by Harding \& Pagan (2001), is designed to adjust the initial indicator for potential biases. Harding \& Pagan (2001) note that the original IC measure might be overstated in the case of two variables that experience prolonged expansion during the period of study. Prolonged growth over a number of consecutive periods is a common feature of real estate and economic cycles' data. Therefore, with regard to a possible bias in the concordance index statistic, the authors propose the Mean Corrected Measure of IC (MCIC) under the assumption of no relation between two series. In comparison with the original IC statistic, the MCIC measures the proportion of time that two series are expected to share in the same phase under an assumption of independence. The adapted MCIC measure is as follows:

$$
\text { MCIC }=2 \mathrm{~T}^{-1} \sum_{\mathrm{t}=1}^{\mathrm{T}}\left\{\left(\mathrm{S}_{\mathrm{it}}-\overline{\mathrm{S}}_{\mathrm{i}}\right)\left(\mathrm{S}_{\mathrm{jt}}-\overline{\mathrm{S}}_{\mathrm{j}}\right)\right\}
$$

Where: 


$$
\begin{aligned}
& \overline{\mathrm{S}}_{\mathrm{i}}=\mathrm{T}^{-1} \sum_{\mathrm{t}=1}^{\mathrm{T}} \mathrm{S}_{\mathrm{it}} \\
& \overline{\mathrm{S}}_{\mathrm{j}}=\mathrm{T}^{-1} \sum_{\mathrm{t}=1}^{\mathrm{T}} \mathrm{S}_{\mathrm{jt}}
\end{aligned}
$$

This methodology has been widely used not only in the context of business cycles (e.g. Altavilla, 2004, Harding \& Pagan, 2001, 2002), but also in office markets (Jackson et al., 2008). However, both concordance measures can be difficult to assess and interpret. The Mean Corrected Index of Concordance is unlikely to exceed 0.5 , whilst the assumption of independence is a strong assumption to make. The original IC values lie within the interval $[0,1]$, where 1 implies perfect synchronization. In this case, the value of 0.5 would mean no particular relation between two series. However, the values that exceed 0.5 cannot be interpreted as statistically meaningful based on the index value information. To overcome such limitations, Harding and Pagan (2006) propose an alternative meancorrected measure of concordance $\left(\hat{I}_{t}\right)$, which also allows one to draw inferences about the concordance index values.

Harding and Pagan show that $\hat{I}_{\mathrm{t}}$ and the empirical correlation between two series $\left(\hat{\rho}_{\mathrm{S}}\right)$ are monotonically related and the significance of $\hat{\rho}_{\mathrm{S}}$ implies significance of $\hat{\mathrm{I}}_{\mathrm{t}}$. They express the revised concordance index as follows:

$$
\hat{\mathrm{I}}_{\mathrm{t}}=1+2 \hat{\rho}_{\mathrm{s}} \sigma_{\mathrm{s}_{\mathrm{x}}} \sigma_{\mathrm{s}_{\mathrm{y}}}+2 \mu_{\mathrm{s}_{\mathrm{x}}} \mu_{\mathrm{s}_{\mathrm{y}}}-\mu_{\mathrm{s}_{\mathrm{x}}}-\mu_{\mathrm{s}_{\mathrm{y}}}
$$

where $\mu_{\mathrm{s}_{\mathrm{i}}}$ and $\sigma_{\mathrm{s}_{\mathrm{i}}}$ are the average and standard deviation of the state variables $\mathrm{S}_{\mathrm{i}}(\mathrm{i}=\mathrm{x}, \mathrm{y})$ and $\hat{\rho}_{\mathrm{S}}$ is the correlation between $S_{\mathrm{xt}}$ and $\mathrm{S}_{\mathrm{yt}}$. The value of $\hat{\rho}_{\mathrm{S}}$ and inferences concerning it can be derived using the following OLS regression: 


$$
\frac{\mathrm{S}_{\mathrm{y}_{\mathrm{t}}}}{\sigma_{\mathrm{s}_{\mathrm{x}}} \sigma_{\mathrm{s}_{\mathrm{y}}}}=\hat{\alpha}+\hat{\rho}_{\mathrm{s}} \frac{\mathrm{S}_{\mathrm{x}_{\mathrm{t}}}}{\sigma_{\mathrm{s}_{\mathrm{x}}} \sigma_{\mathrm{s}_{\mathrm{y}}}}+\varepsilon_{\mathrm{t}}
$$

In order to control for positive serial correlation inherent in $S_{\mathrm{yt}}$, the $\hat{\rho}_{\mathrm{S}}$ test-statistics are estimated using robust standard errors obtained via the HAC procedure. Harding and Pagan also note that the alternative estimation of the index via the $\hat{\rho}_{\mathrm{S}}$ provides an alternative mean-corrected measure of concordance. Since the assumption is that we measure concordance of two independent series, the regression helps us to identify which relations between two series are significant and validate the information about the degree of their synchronisation. In a case when $\hat{\rho}_{\mathrm{S}}$ is insignificant, the high concordance between two series might be caused by the prolonged expansion phase in both series during the time period under examination, which is a common feature of both real estate and macroeconomic data. The empirical analysis is conducted on a pairwise basis across all twenty markets. Both the rental and capital value series are considered and in both real and nominal terms.

\section{4: Empirical Analysis}

We initially concentrate upon the empirical findings with respect to the rental series; we then expand this to consider the changes in property values. The rationale behind this is that the economic diversification argument would intuitively be expected to impact upon rental values. The common economic driving forces, relating to the role of financial services, would be expected to have a common effect upon occupier demand, and therefore possibly lead to increased synchronisation across the markets. Any common movement in capital values adds to this impact the effect of common investor behaviour.

Table 4 presents the modified concordance indicators using the Harding \& Pagan (2006) methodology, and the estimates of Rho from each of the pairwise regressions are reported in Table 5. As noted in Section 3, these provide information regarding the significance of the concordance indicators. In both tables the upper triangle reports the nominal results, and the lower one presents the 
findings with respect to changes in real rents. The results show a high degree of concordance, and more importantly, a level of synchronisation that is statistically significant. In addition, whilst the majority of the markets display a significant level of concordance, there are also indications of continental effects - consistent with findings in papers such as Goeztmann \& Wachter (2001).

Within each continental area there is substantial evidence of concordance. This is particularly evident in the case of the United States. In both nominal and real terms, every pairing provides a significant result. This is also the case with respect to the Asian markets of Hong Kong, Singapore and Tokyo. Sydney appears to be slightly discordant with these markets; the only significant finding being that for nominal rents when it is paired with Singapore. Europe, however, provides a greater intra-continental level of variation. Of the 36 European pairings, 14 are not significant in nominal terms and eight in real terms. To some degree there appears to a level of differentiation between the major global cities and remaining markets. The City of London market, for example, is not significantly synchronised with Frankfurt or Amsterdam in nominal terms, while the West End adds Paris, Milan and Edinburgh to this list. In contrast, as an example of a smaller centre, Edinburgh has significant results with respect to every European market with the exception of the West End. There are also a large number of markets for which Paris does not report significant findings. Indeed, in nominal terms the only significant rho's are with reference to the pairings with Madrid, City of London and Edinburgh ${ }^{9}$. The overall inconsistency in the European findings is of interest particularly in the context of monetary union.

On a global level, there are a number of interesting findings. Whilst London's two markets are not synchronised with most of other European markets, they are with many markets elsewhere. The City of London's office market is significantly synchronised with all non-European markets in real terms and all but Hong Kong in nominal terms. The West End is synchronised with all markets with the exception of Hong Kong (nominal and real) and Sydney (real). This effect is also clearly evident with respect to Paris, which has significant rho's for every non-European market with the exception of Sydney in nominal terms, whilst Boston and Chicago are also not significant in real terms. In contrast, 
some of the other European markets, particularly Frankfurt, Milan and Amsterdam, show very few significant rho's. The lack of significant results with respect to the Asian cities, particularly in relation to a number of the US markets, is striking. No significance is reported for pairings that include Hong Kong, and neither Chicago nor Los Angeles are synchronised with Singapore or Tokyo. However, it is notable that Sydney rental values seem to behave similarly in terms of concordance with all of the American metropolitan areas.

The corresponding findings with respect to capital values are reported in Tables 6 and 7. The results are broadly similar to those relating to rents. As with the rental figures, London and Paris have a higher degree of concordance with American and Asia-Pacific markets than with other European markets. Indeed, the City of London is synchronised with every US and Asia-Pacific market. Similar results as reported with regard to rents are also found in terms of the interlinkages across Asian and US markets, Hong Kong's relative lack of concordance with other markets, and Sydney's strong connections with the US. Whilst the results do reveal some evidence of continental discordance, the overall degree of concordance is quite evident. This is particularly so in the case of London and to some degree Paris and also New York. This is consistent not only with their roles as three of the largest office markets, but also with the global cities literature - which generally place London and New York as the two core global cities.

The similarities in the cyclical behaviour of the majority of the world's office markets raises the question as to why, if diversification opportunities are reduced, investors pursue a portfolio strategy that involves such a degree of concentration in a small number of interconnected markets. The concentration of investment can be viewed in the context of a constraint property investors continually face, namely one of availability of product. Real estate is a relatively small asset class; this can be seen by comparing the overall values of real estate with that of other asset classes. RREEF Research (2007) estimate that in 2006 the value of all invested real estate globally was US\$7.8tr. If one extends the definition to consider all investable real estate, thereby including owner-occupied properties, the figure rises to US $\$ 12.4$ tr. Compared to the total value of other asset classes, this is a 
relatively small amount. For example, the World Federation of Exchanges estimate that at the end of 2009 , the total market capitalisation of global stock exchanges stood at US $\$ 49 \operatorname{tr}$, of which US $\$ 15 \mathrm{tr}$ was in the US markets alone. The Securities Industry and Financial Markets Association (SIFMA) estimate that in 2009 the total amount of fixed income securities outstanding in the United States alone was US\$34tr ${ }^{10}$.

Furthermore, the nature of real estate as an indivisible asset that is held for relatively long holding periods also has an impact. As only a small proportion will be available for transaction at any one time, transaction volume is relatively low. This can be illustrated using stock and flow figures. RREEF Research (2007) estimate that the value of European real estate in 2006 was US\$2.4tr, and Jones Lang LaSalle (2010) estimate that annual investment volume in European real estate averaged only $€ 138 \mathrm{bn}$ during the 2000 s, reaching a peak of over $€ 250 \mathrm{bn}$ in 2006 . In contrast, capital market assets are highly divisible and highly liquid, and huge volumes are traded each year. Whereas World Federation of Exchanges data reveals that the market capitalisation of the US equity markets stood at US \$15tr in 2009, trading volume during the year was in excess of US \$46tr. During the ten years from 2000, the ratio of trading volume to market capitalisation averaged 2.31, and has been consistently above 1 since 1998. With respect to the fixed income market, SIFMA data illustrates that trading volume in the US bond market has exceeded US \$200tr in each year since 2004 and that the average ratio of trading volume to debt outstanding was in excess of 7 during the last decade. These figures highlight that not only is real estate is a relatively small asset class, but that there is far less trading activity in real estate compared to financial assets. The global office markets, however, have a major advantage relative to smaller property markets - enhanced availability of product and higher liquidity. Liquidity risk is the most important primary risk factor for institutional investors in the context of property investment, as illustrated by Dhar \& Goeztmann (2005). It may therefore be that global investors view the possible benefits from investing in deeper and more liquid markets sufficient to offset any loss of diversification benefit. 
The concentration of investment may also lead to further risk factors. If global investors are increasingly dominating investment in major office markets, then it is possible that such centres are subject to flow of funds effects. This means that not only do such markets have common characteristics with respect to the occupier market and therefore rental income, but also with respect to yield movements. This is an important point as it provides an additional degree of integration between the markets. Whilst we do not see substantial differences between our results using rental and capital value data the study of Jackson et al. (2008) did provide supporting empirical evidence in the context of New York and London. Indeed, in some respects this can also be linked back to the global cities literature. Castells (1996) argues that issues such as the flow of information and capital through the global cities is more important than their fixed attributes. Lizieri (2009b) makes a similar, but not identical, point. He argues that the fact that so many investors are also financial services firms can lead to increased risk and volatility.

It may be the case that that investors would be better served by expanding their investment portfolio into smaller regional markets. However, this is subject to two key issues being satisfied. Firstly, that regional markets behave sufficiently differently from the major centres, and secondly, that investors are prepared to alter their investment strategies in such a way. In relation to the first point, the current study does not explicitly consider the behaviour of regional provincial markets and furthermore, the existing empirical evidence in the context of most major markets is relatively limited. However, the available evidence suggests that the degree of divergence varies country to country; whereas in some markets such benefits may be observed, it may not be the case in others. In relation to investor behaviour, real estate is a relatively small asset class, and it is also an illiquid one. Investors value the importance of both the size and depth of a market and its relative liquidity (Dhar \& Goeztmann, 2005). The problem that many smaller regional markets face is that they are potentially insufficiently liquid to attract institutional interest. The combined effect for a major institutional investor is a tradeoff between economic diversification and liquidity. If an investor has a preference for enhanced liquidity then this leaves them with the challenge of achieving diversification within an integrated system of office markets. 


\section{5: Concluding Comments}

This paper has considered the level of concordance between twenty of the largest office markets globally. The results highlight the degree of synchronisation in the cyclical behaviour of the markets considered. The importance of these findings are in relation to the diversification benefits available to international real estate fund managers, especially in light of the fact that such a high proportion of cross-border investment is concentrated in key markets such as London and New York. The combination of common underlying economic driving forces and common investors effectively means that global real estate investors are gaining little in terms of diversification, and are therefore also increasing their risk, by concentrating investment in these markets. This paper highlights that whilst institutional investors may be constrained due to risk factors such as liquidity, the pursuit of an investment strategy that is concentrated in global cities has its own consequences. We clearly show that there are previously unrecognised risks involved in such a strategy. This applies not only in the context of real estate-only portfolios. Multi-asset class portfolio managers are also potentially affected due to the linkages between the global office markets and the broad capital markets. This means that such managers may not be obtaining the asset-class diversification benefits associated with real estate investment. 


\section{References:}

Amin, A. \& Thrift, N. (1997). Globalization, Socio-Economics, Territoriality, in Lee, R. \& Wills, J., Geographies of Economies, London: Edward Arnold.

Ammer, J. \& Mei, J. (1996).Measuring International Economics Linkages with Stock Market Data, Journal of Finance, 51, 1743-1763.

Altavilla, C. (2004). Do EMU Members Share the Same Business Cycle, Journal of Common Market Studies, 42, 869-896.

Beaverstock, J.V. \&Boardwell, J.T. (2000). Negotiating Globalization, Transnational Corporations and Global City Financial Centres in Transient Migration Studies, Applied Geography, 20, 277-304.

Beaverstock, J.V. \& Smith, J. (1996).Lending Jobs to Global Cities: Skilled International Labour Migration, Investment Banking and the City of London, Urban Studies, 33, 1377-1394.

Beaverstock, J.V., Smith, R.G., Taylor, P.J., Walker, D.R.F. \&Lorimer, H. (2000). Globalization and World Cities: Some Measurement Methodologies, Applied Geography, 20, 43-63.

Bekaert, G. \& Harvey, C.R. (1995). Time-Varying World Market Integration, Journal of Finance,50, 403-444.

Bekaert, G., Harvey, C.R. \&Lumsdaine, R.L. (2002).Dating the Integration of World Equity Markets, Journal of Financial Economics, 65, 203-247.

Bekaert, G., Harvey, C.R. \&Lundblad, C. (2005). Does Financial Liberalization Spur Growth, Journal of Financial Economics, 77, 3-55.

Bekaert, G., Harvey, C.R. \&Lundblad, C. (2006). Growth Volatility and Financial Liberalization, Journal of International Money and Finance, 25, 370-403.

Brooks, C. \&Tsolacos, S. (2008). Integration of International Office Markets and Signal Extraction, Journal of Real Estate Portfolio Management, 14, 351-361.

Candelon, B., Piplack, J. \&Straetmans, S. (2008). On Measuring Synchronization of Bulls and Bears: The Case of East Asia, Journal of Banking \& Finance, 32, 1022-1035.

Case, B., Goetzmann, W. and Rouwenhorst, G. (2000). Global Real Estate Markets: Cycles and Fundamentals,NBER Working Paper, 7566.

Castells, M. (1996). The Rise of the Network society, Oxford: Blackwell.

Chua, A. (1999) The role of international real estate in global mixed-asset investment portfolios, Journal of Real Estate Portfolio Management, 5, 129-137. 
Coakley, J. (1994). The Integration of Property and Financial Markets, Environment and Planning A, 26, 697-713.

Conner, P. \& Liang, Y. (2005). Ask Not Why International, Ask Why Not International, Prudential Real Estate Investors Research Report, June 2005.

D’Arcy, E., McGough, T. and Tsolacos, S. (1997). National Economic Trends, Market Size and City Growth Effects on European Office Rents, Journal of Property Research, 14, 297-307.

De Wit, I. (2010). International Diversification Strategies for Direct Real Estate, Journal of Real Estate Finance and Economics, 41, 433-457.

De Wit, I. and Van Dijk, R. (2003). Global Determinants of Direct Office Real Estate Returns, Journal of Real Estate Finance and Economics, 26, 27-25.

Dehaesh, A. \& Pugh, C. (1999). The Internalization of Post-1980 Property Cycles and the Japanese 'Bubble' Economy, 1986-96, International Journal of Urban and Regional Research, 23, 147-164.

Dehaesh, A. \& Pugh, C. (2000b). Property Cycles in a Global Economy, Urban Studies, 37, 25812602.

Deutsche Bank Research (2010).Global Financial Centers after the Crisis, EU Monitor 76, August 2010.

Dhar, R. \& Goetzmann, W.N. (2005). Institutional Perspectives on Real Estate Investing: The Role of Risk and Uncertainty, Pension Real Estate Association Research Report.

Derudder, B. \& Taylor, P. (2005). The Cliqueishness of World Cities, Global Networks, 5, 71-91.

Derudder, B., Taylor, P., Witlock, F. \& Catalano, G. (2003). Hierarchical Tendencies and Regional Patterns in the World City Network, Regional Studies, 37, 875-886.

Engle, R.F. \&Issler, J.V. (1995).Estimating Common Sectoral Cycles, Journal of Monetary Economics, 35, 83-113.

Engle, R.F., Ito, T. \& Lin, W.L. (1994). Do Bulls and Bears Move Across Borders ? International Transmissions of Stock Price Volatility, Review of Financial Studies, 7, 507-538.

Farrelly, K. \& Sanderson, B. (2005).Modeling Regime Shifts in the City of London Office Rental Cycle, Journal of Property Research, 22, 325-344.

Findlay, A.M., Li, F.L.N., Jowett, A.J. \& Skelton, R. (1996). Skilled International Migration and the Global City: A Study of Expatriates in Hong Kong, Transactions of the Institute of British Geographers, 21, 49-61.

Friedman, J. (1986). The World City Hypothesis, Development and Change, 17, 69-83. 
Friedman, J. (1995). Where we Stand: A Decade of World City Research, in Knox, P. \& Taylor, P.J. (eds). World Cities in a World System, Cambridge: Cambridge University Press.

Friedman, J. \& Wolff, G. (1982). World City Formation, an Agenda for Research and Action, International Journal of Urban and Regional Research, 6, 309-344.

Froland, C., Gorlow, R. \& Sampson, R. (1986). The Market Risk of Real Estate, Journal of Portfolio Management, 12:3, Spring, 12-19.

Goeztmann, W.N. \& Wachter, S.M. (1995). Clustering Methods for Real Estate Portfolios, Real Estate Economics, 23, 271-310.

Goetzmann, W.N.\& Wachter, S.M. (2001).The Global Real Estate Crash: Evidence from an International Database, in Brown, S.J. \& Liu, C.H. (Eds). A Global Perspective on Real Estate Cycles, Boston MA: Kluwer Academic Publishers.

Gregory, A.W. \& Hansen, R.E. (1996).Residual-based Tests for Co-Integration in the Models with Regime Shifts. Journal of Econometrics, 70, 99-126.

Guissani, B., Hsia, M. \& Tsolacos, S. (1993). A Comparative Analysis of the Major Determinants of Office Rental Values in Europe, Journal of Property Investment and Valuation,11, 157-172.

Hamelink, F., Hoesli, M., Lizieri, C. and MacGregor, B.D. (2000). Homogeneous Commercial Property Markets Groupings and Portfolio Construction in the United Kingdom, Environment and Planning A, 32, 323-344.

Harding, D. \& Pagan, A. (2002).Dissecting the Cycle: A Methodological Investigation, Journal of Monetary Economics, 49, 365-381.

Harding, D. \& Pagan, A. (2006).Synchronization of Cycles, Journal of Econometrics, 132, 59-79.

Heathcote, J. \& Perri, F. (2004). Financial Globalization and Real Regionalization, Journal of Economic Theory, 119, 207-243.

Hendershott, P., Lizieri, C. \& MacGregor, B. (2010). Asymmetric Adjustment in the City of London Office Market, Journal of Real Estate Finance \& Economics, forthcoming.

Hendershott, P., Lizieri, C. \& Matysiak, G. (1999). The Workings of the London Office Market, Real Estate Economics, 27, 265-387.

Hoesli, M., Lekander, J. and Witkiewicz, W. (2004). International Evidence on Real Estate as a Portfolio Diversifier, Journal of Real Estate Research, 26, 161-206.

Hoesli, M., Lizieri, C. and MacGregor, B.D. (1997) The Spatial Dimensions of the Investment Performance of UK Commercial Property, Urban Studies, 34, 1475-1494. 
Jackson, C. (2002). Classifying Local Retail Property Markets and the Basis of Retail Rental Growth Rates, Urban Studies, 39, 1417-1438.

Jackson, C., Stevenson, S. \& Watkins, C. (2008). NY-LON: Does a Single Cross-Continental Office Market Exist ?, Journal of Real Estate Portfolio Management, 14, 79-92.

Jones Lang LaSalle (2007). European Capital Markets Bulletin H1 2007, July 2007.

Jones Lang LaSalle (2008). Overseas Investors - Influence on the Rise, October 2008.

Jones Lang LaSalle (2009a). European Capital Markets Bulletin, March 2009.

Jones Lang LaSalle (2009b). European Capital Markets Bulletin, July 2009.

Jones Lang LaSalle (2010). European Capital Markets Bulletin, March 2010.

Kapas, M. \& Liang, Y. (2010). A Bird's Eye View of Global Real Estate Markets: 2010 Update, Prudential Real Estate Investors Research Report, March 2010.

Kindelberger, C. (1974). The Formation of Financial Centers: A Study of Comparative Economic History, Princeton Studies in International Finance 36.

Liow, K.H. (2010). International Direct Real Estate Market Linkages: Evidence from Time-Varying Correlation and Cointegration Tests, Journal of Real Estate Literature, 18, 283-312.

Lizieri, C. (2009a). Towers of Capital: Office Markets and International Financial Services, London: Wiley-Blackwell

Lizieri, C. (2009b). Real Estate Investment in Global Financial Centres: Risk, Return and Contagion, Working Paper, School of Real Estate \& Planning, University of Reading, 11/09.

Lizieri, C., Baum, A. \&Scott, P. (2000). Ownership, Occupation and Risk: A View of the City of London Office Market, Urban Studies, 37, 1109-1129.

Lizieri, C. \&Kutsch, N. (2006). Who Owns the City 2006: Office Ownership in the City of London, School of Real Estate \& Planning, University of Reading and Development Securities plc.

MacGregor, B.D. \& Schwann, G.M. (2003). Common Features in UK Commercial Real Estate Returns, Journal of Property Research, 20, 23-48.

Myer, F.C.N., Chaudhry, M.K. \& Webb, J.R. (1997). Stationarity and Co-integration in Systems with Three National Real Estate Indexes, Journal of Real Estate Research, 13, 369-381.

Quan, D. \&Titman, S. (1997). Commercial Real Estate Prices and Stock Market Returns: An International Analysis, Financial Analysts Journal,53:3, 21-34.

Quan, D. \&Titman, S. (1999). Do Real Estate Prices and Stock Prices Move Together? An International Comparison, Real Estate Economics,27, 183-208. 
Renaud, B. (1997). The 1985 to 1994 Global Real Estate Cycle: An Overview, Journal of Real Estate Literature, 5, 13-44.

RREEF Research (2007).Global Real Estate Insights: Into the Cyclical Downturn, October 2007.

Sassen, S. (1988).The Migration of Capital and Labour, Cambridge: Cambridge University Press.

Sassen, S. (1991).The Global City, Princeton NJ: Princeton University Press.

Sassen, S. (1994).Cities in a World Economy, London: Pine Forge Press.

Shigemi, Y. (1995). Asset Inflation in Selected Countries, Bank of Japan Monetary and Economic Studies, 13, 89-130.

Sirmans, C.F. \&Worzala, E. (2003). International Direct Real Estate Investment: A Review of the Literature, Urban Studies, 40, 1081-1114.

Smith, D.A. \& Timberlake, M. (1995). Conceptualising and Mapping the Structure of the World Systems City System, Urban Studies, 32, 287-302.

Stevenson, S. \& Young, J. (2011).Capital Market Expectations and the London Office Market, Working Paper, School of Real Estate \& Planning, University of Reading.

Taylor, P. \& Aranya, R. (2008).A Global 'Urban Roller Coaster'? Connectivity Changes in the World City Network, 2000-2004, Regional Studies, 42, 1-16.

Taylor, P.J., Catalano, G. \& Walker, D.R.F. (2002a). Measurement of the World City Network, Urban Studies, 39, 2367-2376.

Taylor, P.J., Catalano, G. \& Walker, D.R.F. (2002b). Exploratory Analysis of the World City Network, Urban Studies, 39, 2367-2376.

Wang, P. (2003). A Frequency Domain analysis of Common Cycles in Property and Related Sectors, Journal of Real Estate Research, 25, 325-346.

Webb, J. \&O'Keefe, J. (2002).The Case for Global Real Estate, Working Paper, UBS Global Asset Management.

Wheaton, W.C. (1999). Real Estate 'Cycles': Some Fundamentals, Real Estate Economics, 27, 209230.

Wheaton, W.C., Torto, R.G. and Evans, P. (1997). The Cyclic Behavior of the Greater London Office Market, Journal of Real Estate Finance and Economics, 15, 77-92.

Worzala, E. (1994). Overseas Property Investments: How are They Perceived by the Institutional Investor?,Journal of Property Valuation and Investment, 12, 31-47. 
Ziobrowski, A. \&Curcio, R. (1991). Diversification Benefits of US Real Estate to Foreign Investors, Journal of Real Estate Research, 6, 119-142.

Ziobrowski, A. \&Ziobrowski, B. (1993).Hedging Foreign Investments in US Real Estate with Currency Options, Journal of Real Estate Research, 8, 27-54.

Ziobrowski, A., Ziobrowski, B. \& Rosenberg, S. (1997). Currency Swaps and International Real Estate Investment, Real Estate Economics, 25, 223-251. 
Table 1: GFCI Rankings of Global Financial Centres

\begin{tabular}{lcc}
\hline & GFCI 8 Rank & GFCI 7 Rank \\
\hline London & 1 & $=1$ \\
New York & 2 & $=1$ \\
Hong Kong & 3 & 3 \\
Singapore & 4 & 4 \\
Tokyo & 5 & 5 \\
Shanghai & 6 & 11 \\
Chicago & 7 & 6 \\
Zurich & 8 & 7 \\
Geneva & 9 & 8 \\
Sydney & 10 & $9=$ \\
\hline
\end{tabular}

Notes: Table 1 reports the rankings of the Global Financial Centers Index, produced by the Qatar Financial Centre 
Table 2: Average Returns

\begin{tabular}{lcccc}
\hline & Nominal Rents & Real Rents & Nominal Capital Values & Real Capital Values \\
\hline Paris & $0.2192 \%$ & $-0.1936 \%$ & $-0.1105 \%$ & $-0.5203 \%$ \\
Frankfurt & $0.0118 \%$ & $-0.4495 \%$ & $-0.2632 \%$ & $-0.7198 \%$ \\
Milan & $0.5001 \%$ & $-0.2261 \%$ & $0.4698 \%$ & $-0.2575 \%$ \\
Amsterdam & $0.7539 \%$ & $0.2022 \%$ & $0.8128 \%$ & $0.2618 \%$ \\
Barcelona & $-0.1789 \%$ & $-0.9860 \%$ & $-0.2203 \%$ & $-1.0246 \%$ \\
Madrid & $0.0406 \%$ & $-0.7700 \%$ & $-0.1558 \%$ & $-0.9629 \%$ \\
London: City & $-0.2775 \%$ & $-0.8195 \%$ & $-0.1809 \%$ & $-0.7216 \%$ \\
London: West End & $0.4437 \%$ & $-0.1075 \%$ & $0.8970 \%$ & $0.3407 \%$ \\
Edinburgh & $0.4516 \%$ & $-0.1007 \%$ & $0.6298 \%$ & $0.0727 \%$ \\
Boston & $0.2925 \%$ & $-0.3449 \%$ & $0.0070 \%$ & $-0.6266 \%$ \\
Chicago & $0.5475 \%$ & $-0.0881 \%$ & $-0.5608 \%$ & $-1.1898 \%$ \\
Los Angeles & $-0.0478 \%$ & $-0.6821 \%$ & $-0.9166 \%$ & $-1.5437 \%$ \\
New York & $0.7359 \%$ & $0.0969 \%$ & $-0.2486 \%$ & $-0.8808 \%$ \\
San Francisco & $1.0770 \%$ & $0.4344 \%$ & $0.2051 \%$ & $-0.4299 \%$ \\
Seattle & $0.6180 \%$ & $-0.0195 \%$ & $0.3481 \%$ & $-0.2877 \%$ \\
Washington D.C. & $0.2731 \%$ & $-0.3607 \%$ & $-0.0479 \%$ & $-0.6809 \%$ \\
Hong Kong & $0.7321 \%$ & $0.0637 \%$ & $1.7144 \%$ & $1.0363 \%$ \\
Singapore & $0.2341 \%$ & $-0.1640 \%$ & $0.3873 \%$ & $-0.0131 \%$ \\
Tokyo & $-0.7590 \%$ & $-0.7997 \%$ & $0.6776 \%$ & $0.7524 \%$ \\
Sydney & $0.5159 \%$ & $-0.1073 \%$ & $0.6422 \%$ & $0.0188 \%$ \\
\hline
\end{tabular}

Notes: Table 2 presents the average quarterly returns for each of the twenty office markets. Both rental and capital value returns are reported and in both nominal and real terms. 
Table 3: Average Figures for State Variables

\begin{tabular}{|c|c|c|c|c|}
\hline & Nominal Rents & Real Rents & Nominal Capital Values & Real Capital Values \\
\hline Paris & 0.2400 & 0.2400 & 0.3467 & 0.3467 \\
\hline Frankfurt & 0.1733 & 0.2133 & 0.2000 & 0.2400 \\
\hline Milan & 0.2533 & 0.2800 & 0.3067 & 0.3067 \\
\hline Amsterdam & 0.2267 & 0.2933 & 0.2800 & 0.3067 \\
\hline Barcelona & 0.2800 & 0.2933 & 0.3733 & 0.3600 \\
\hline Madrid & 0.3733 & 0.3733 & 0.4267 & 0.4133 \\
\hline London: City & 0.4267 & 0.4267 & 0.4533 & 0.4667 \\
\hline London: West End & 0.3733 & 0.4000 & 0.4667 & 0.4800 \\
\hline Edinburgh & 0.2667 & 0.2933 & 0.3867 & 0.3733 \\
\hline Boston & 0.5733 & 0.5333 & 0.5333 & 0.5333 \\
\hline Chicago & 0.6000 & 0.4400 & 0.4267 & 0.3200 \\
\hline Los Angeles & 0.4800 & 0.3467 & 0.4800 & 0.3867 \\
\hline New York & 0.6933 & 0.6133 & 0.6400 & 0.4933 \\
\hline San Francisco & 0.6133 & 0.5867 & 0.5333 & 0.5333 \\
\hline Seattle & 0.5733 & 0.4533 & 0.5333 & 0.4933 \\
\hline Washington D.C. & 0.5200 & 0.4667 & 0.5333 & 0.4400 \\
\hline Hong Kong & 0.5467 & 0.5200 & 0.5867 & 0.6000 \\
\hline Singapore & 0.4400 & 0.4267 & 0.2800 & 0.3200 \\
\hline Tokyo & 0.3200 & 0.3333 & 0.5641 & 0.5897 \\
\hline Sydney & 0.5797 & 0.4203 & 0.6957 & 0.5507 \\
\hline
\end{tabular}

Notes: Table 3 presents the average figures for the State Variables for each of the twenty office markets. Both rental and capital value returns are reported and in both nominal and real terms. 
Table 4: Concordance Indicator Rents

\begin{tabular}{|c|c|c|c|c|c|c|c|c|c|c|c|c|c|c|c|c|c|c|c|c|}
\hline & Par & Fran & Mil & Ams & Bar & Mad & City & LWE & Edin & Bos & Chi & LA & NYC & SF & Sea & $\mathrm{DC}$ & HK & Sing & Tok & Syd \\
\hline Paris & - & 0.757 & 0.692 & 0.694 & 0.689 & 0.714 & 0.661 & 0.667 & 0.704 & 0.547 & 0.522 & 0.633 & 0.511 & 0.557 & 0.547 & 0.618 & 0.571 & 0.648 & 0.746 & 0.548 \\
\hline Frankfurt & 0.765 & - & 0.770 & 0.680 & 0.809 & 0.711 & 0.598 & 0.648 & 0.733 & 0.524 & 0.542 & 0.609 & 0.417 & 0.489 & 0.565 & 0.573 & 0.488 & 0.586 & 0.657 & 0.480 \\
\hline Milan & 0.689 & 0.760 & - & 0.709 & 0.807 & 0.728 & 0.627 & 0.608 & 0.771 & 0.537 & 0.560 & 0.670 & 0.501 & 0.500 & 0.537 & 0.586 & 0.468 & 0.591 & 0.637 & 0.552 \\
\hline Amsterdam & 0.676 & 0.674 & 0.692 & - & 0.676 & 0.607 & 0.580 & 0.584 & 0.766 & 0.533 & 0.578 & 0.619 & 0.448 & 0.474 & 0.556 & 0.560 & 0.445 & 0.522 & 0.588 & 0.499 \\
\hline Barcelona & 0.701 & 0.794 & 0.797 & 0.680 & - & 0.782 & 0.654 & 0.659 & 0.776 & 0.588 & 0.588 & 0.699 & 0.530 & 0.551 & 0.612 & 0.637 & 0.516 & 0.641 & 0.715 & 0.539 \\
\hline Madrid & 0.714 & 0.709 & 0.708 & 0.622 & 0.798 & - & 0.755 & 0.787 & 0.750 & 0.741 & 0.691 & 0.804 & 0.691 & 0.758 & 0.741 & 0.764 & 0.610 & 0.715 & 0.823 & 0.587 \\
\hline London: City & 0.661 & 0.612 & 0.557 & 0.570 & 0.644 & 0.755 & - & 0.684 & 0.667 & 0.773 & 0.776 & 0.810 & 0.752 & 0.764 & 0.773 & 0.823 & 0.533 & 0.693 & 0.746 & 0.705 \\
\hline London: West End & 0.664 & 0.660 & 0.583 & 0.596 & 0.645 & 0.757 & 0.762 & - & 0.662 & 0.715 & 0.612 & 0.726 & 0.663 & 0.679 & 0.689 & 0.687 & 0.558 & 0.637 & 0.685 & 0.558 \\
\hline Boston & 0.560 & 0.579 & 0.529 & 0.590 & 0.590 & 0.726 & 0.758 & 0.755 & 0.639 & - & 0.816 & 0.850 & 0.906 & 0.940 & 0.947 & 0.863 & 0.573 & 0.732 & 0.650 & 0.705 \\
\hline Chicago & 0.602 & 0.710 & 0.641 & 0.655 & 0.582 & 0.637 & 0.666 & 0.691 & 0.679 & 0.775 & - & 0.820 & 0.788 & 0.775 & 0.863 & 0.807 & 0.441 & 0.599 & 0.565 & 0.707 \\
\hline Los Angeles & 0.694 & 0.736 & 0.661 & 0.700 & 0.751 & 0.845 & 0.769 & 0.794 & 0.777 & 0.829 & 0.729 & - & 0.811 & 0.794 & 0.857 & 0.853 & 0.533 & 0.641 & 0.635 & 0.723 \\
\hline New York & 0.557 & 0.507 & 0.478 & 0.491 & 0.566 & 0.652 & 0.764 & 0.735 & 0.566 & 0.875 & 0.725 & 0.701 & - & 0.900 & 0.806 & 0.777 & 0.631 & 0.703 & 0.624 & 0.651 \\
\hline San Francisco & 0.581 & 0.530 & 0.527 & 0.540 & 0.590 & 0.729 & 0.788 & 0.732 & 0.639 & 0.925 & 0.749 & 0.750 & 0.889 & - & 0.874 & 0.819 & 0.611 & 0.716 & 0.662 & 0.642 \\
\hline Seattle & 0.635 & 0.675 & 0.604 & 0.642 & 0.642 & 0.779 & 0.785 & 0.730 & 0.691 & 0.867 & 0.852 & 0.826 & 0.780 & 0.836 & - & 0.863 & 0.546 & 0.706 & 0.650 & 0.676 \\
\hline Washington D.C. & 0.691 & 0.618 & 0.615 & 0.653 & 0.629 & 0.739 & 0.797 & 0.742 & 0.629 & 0.800 & 0.812 & 0.761 & 0.819 & 0.822 & 0.906 & - & 0.520 & 0.654 & 0.679 & 0.737 \\
\hline Hong Kong & 0.618 & 0.482 & 0.469 & 0.481 & 0.578 & 0.661 & 0.639 & 0.611 & 0.554 & 0.587 & 0.387 & 0.557 & 0.611 & 0.612 & 0.533 & 0.547 & - & 0.707 & 0.736 & 0.460 \\
\hline Singapore & 0.661 & 0.568 & 0.582 & 0.545 & 0.668 & 0.703 & 0.707 & 0.652 & 0.619 & 0.709 & 0.507 & 0.648 & 0.677 & 0.732 & 0.627 & 0.614 & 0.722 & - & 0.846 & 0.637 \\
\hline Sydney & 0.603 & 0.611 & 0.652 & 0.667 & 0.660 & 0.652 & 0.673 & 0.585 & 0.671 & 0.718 & 0.684 & 0.750 & 0.673 & 0.687 & 0.728 & 0.702 & 0.539 & 0.627 & 0.540 & - \\
\hline
\end{tabular}

lower in real terms. The Concordance Indicator is estimated using the following formula: $\hat{\mathrm{I}}_{\mathrm{t}}=1+2 \hat{\rho}_{\mathrm{s}} \sigma_{\mathrm{s}_{\mathrm{x}}} \sigma_{\mathrm{s}_{\mathrm{y}}}+2 \mu_{\mathrm{s}_{\mathrm{x}}} \mu_{\mathrm{s}_{\mathrm{y}}}-\mu_{\mathrm{s}_{\mathrm{x}}}-\mu_{\mathrm{s}_{\mathrm{y}}}$ 
Table 5: Estimates of Rho with Rental Data

\begin{tabular}{|c|c|c|c|c|c|c|c|c|c|c|c|c|c|c|c|c|c|c|c|c|}
\hline & Par & Fran & Mil & Ams & Bar & $\mathrm{Mad}$ & City & LWE & Edin & Bos & Chi & LA & NYC & SF & Sea & DC & $\mathrm{HK}$ & Sing & Tok & Syd \\
\hline Paris & - & 0.268 & 0.172 & 0.146 & 0.196 & $0.358 * * * *$ & $0.290 * *$ & 0.244 & $0.218^{*}$ & $0.201^{*}$ & $0.178^{*}$ & $0.286^{* * *}$ & $0.283 * * *$ & $0.279 * * *$ & $0.201 *$ & $0.301 * * *$ & $0.224^{* *}$ & $0.275 * *$ & $0.382 * * * *$ & 0.212 \\
\hline Frankfurt & $0.331 * *$ & - & $0.332 * *$ & 0.004 & $0.487 * * *$ & $0.350^{* * * *}$ & 0.134 & 0.179 & $0.241^{*}$ & $0.193^{*}$ & $0.289 * * *$ & $0.254^{* *}$ & 0.125 & 0.170 & $0.302 * * *$ & $0.226 * *$ & 0.048 & 0.123 & 0.113 & 0.087 \\
\hline Milan & 0.196 & $0.365^{* * * *}$ & - & 0.205 & $0.508 * * *$ & $0.394 * * *$ & $0.212^{*}$ & 0.109 & $0.405^{* * * *}$ & 0.169 & $0.256 * *$ & $0.368 * * *$ & $0.240^{* * *}$ & 0.132 & 0.169 & $0.220^{*}$ & -0.021 & 0.143 & 0.118 & 0.212 \\
\hline Amsterdam & 0.175 & $0.148^{*}$ & $0.247 *$ & - & $0.148^{*}$ & 0.094 & 0.095 & 0.037 & $0.373^{* * * *}$ & $0.177^{*}$ & $0.322 * * *$ & $0.259^{* * * *}$ & 0.139 & 0.088 & $0.232 * * *$ & $0.169^{*}$ & -0.070 & -0.026 & -0.027 & 0.103 \\
\hline Barcelona & $0.239 * *$ & $0.470 * * *$ & $0.504 * * *$ & $0.228 * *$ & - & $0.522 * * *$ & $0.275^{* *}$ & $0.237 * *$ & $0.436^{* * * *}$ & $0.270^{* * *}$ & $0.300 * *$ & $0.423 * * *$ & $0.278 * *$ & $0.232^{*}$ & $0.325^{* * * *}$ & $0.325 * * *$ & 0.082 & $0.258^{* * *}$ & $0.324 * *$ & 0.168 \\
\hline Madrid & $0.358 * * *$ & $0.343 * * *$ & $0.351^{* * *}$ & 0.159 & $0.558^{* * *}$ & - & $0.493 * * *$ & $0.544 * * *$ & $0.445^{* * * *}$ & $0.542^{* * * *}$ & $0.456^{* * *}$ & $0.618^{* * * *}$ & $0.538^{* * * *}$ & $0.609 * * *$ & $0.542 * * *$ & $0.558 * * *$ & 0.253 & $0.416^{* * * *}$ & $0.615^{* * * *}$ & 0.224 \\
\hline London: City & $0.290^{* *}$ & 0.173 & 0.057 & 0.088 & $0.251^{*}$ & $0.493^{* * * *}$ & - & $0.345 * * *$ & $0.305^{* *}$ & $0.581 * * *$ & $0.600^{* * *}$ & $0.622^{* * * *}$ & $0.615^{* * * *}$ & $0.583^{* * * *}$ & $0.581^{* * * *}$ & $0.660^{* * * *}$ & 0.081 & $0.374^{* * * *}$ & $0.475^{* * * *}$ & $0.443^{* * * *}$ \\
\hline London: West End & $0.267 *$ & $0.256 * *$ & 0.089 & 0.122 & $0.233 * *$ & $0.489 * * * *$ & $0.511^{* * * *}$ & - & 0.241 & $0.488 * * *$ & $0.289 * *$ & $0.457 * * *$ & 0.476 **** & 0.440 **** & $0.433 * * * *$ & $0.397 * * *$ & 0.145 & $0.253^{*}$ & $0.309 * *$ & 0.165 \\
\hline Edinburgh & $0.239^{*}$ & $0.534^{* * * *}$ & $0.376^{* * * *}$ & $0.228 * *$ & $0.421^{* * * *}$ & $0.501^{* * * *}$ & $0.425^{* * * *}$ & $0.399 * * *$ & - & $0.356^{* * * *}$ & $0.278^{* * *}$ & $0.342^{* * * *}$ & $0.322 * * * *$ & $0.379^{* * * *}$ & $0.411^{* * *}$ & $0.299^{* * * *}$ & 0.111 & $0.227^{*}$ & 0.221 & 0.143 \\
\hline Boston & 0.182 & $0.239^{* *}$ & 0.096 & $0.229 * *$ & $0.229^{*}$ & $0.486^{* * * *}$ & $0.532^{* * * *}$ & $0.536^{* * * *}$ & $0.336 * *$ & - & $0.622^{* * * *}$ & $0.714^{* * * *}$ & $0.827 * * *$ & $0.879^{* * * *}$ & $0.891^{* * * *}$ & $0.729^{* * * *}$ & 0.134 & 0.491 **** & $0.382^{* * *}$ & $0.396^{* * * *}$ \\
\hline Chicago & 0.167 & $0.431^{* * *}$ & $0.258^{*}$ & $0.288^{* * *}$ & 0.126 & $0.253^{*}$ & $0.320^{* * *}$ & $0.368^{* * *}$ & $0.342^{* *}$ & $0.563^{* * *}$ & - & $0.662^{* * * *}$ & $0.552 * * *$ & $0.528^{* * *}$ & $0.719^{* * *}$ & $0.620^{* * *}$ & -0.140 & 0.227 & 0.221 & $0.396^{* * * *}$ \\
\hline Los Angeles & $0.280^{* *}$ & $0.380^{* * *}$ & $0.219^{*}$ & $0.316^{* * *}$ & $0.434^{* * * *}$ & $0.665^{* * * *}$ & $0.524 * * *$ & $0.565^{* * *}$ & $0.493^{* * * *}$ & $0.714 * * *$ & $0.445^{* * * *}$ & - & $0.692 * * *$ & $0.614 * * *$ & $0.728 * * *$ & $0.709^{* * * *}$ & 0.071 & 0.279 & 0.275 & $0.459^{* * * *}$ \\
\hline New York & $0.279^{* *}$ & 0.179 & 0.063 & 0.085 & $0.253^{* *}$ & $0.384^{* * *}$ & $0.583^{* * *}$ & $0.540^{* * *}$ & $0.253^{* *}$ & $0.757^{* * *}$ & $0.493^{* * *}$ & $0.509^{* * * *}$ & - & $0.793^{* * *}$ & $0.610^{* * *}$ & $0.585^{* * *}$ & 0.246 & $0.494 * * *$ & $0.451^{\text {**** }}$ & $0.264^{*}$ \\
\hline San Francisco & $0.299 * * *$ & $0.199^{*}$ & 0.147 & $0.170^{*}$ & $0.280^{* *}$ & $0.526^{* * *}$ & $0.617^{* * *}$ & $0.517^{* * * *}$ & $0.390^{* * * *}$ & $0.854 * * *$ & $0.530^{* * *}$ & $0.591^{* * * *}$ & $0.771 * * *$ & - & $0.743^{* * *}$ & $0.645^{* * * *}$ & 0.207 & $0.474^{* * * *}$ & $0.446^{* * * *}$ & $0.258^{*}$ \\
\hline Seattle & $0.260^{* * *}$ & $0.363^{* * *}$ & 0.187 & $0.270^{* * *}$ & $0.270^{* *}$ & $0.555^{* * *}$ & $0.565^{* * *}$ & $0.452^{* * * *}$ & $0.378^{* * * *}$ & $0.746^{* * *}$ & $0.702 * * *$ & $0.657^{* * * *}$ & $0.600 * * *$ & $0.702^{* * * *}$ & - & $0.729^{* * * *}$ & 0.080 & $0.437^{* * * *}$ & $0.382^{* * *}$ & $0.336^{* *}$ \\
\hline Washington D.C. & $0.407 * * *$ & $0.243^{* *}$ & $0.225 *$ & $0.307 * * *$ & $0.254 *$ & $0.479^{* * *}$ & $0.593^{* * *}$ & $0.482^{* * *}$ & $0.254 *$ & $0.607^{* * *}$ & $0.621^{* * *}$ & $0.529 * * *$ & $0.671^{* * * *}$ & $0.668^{* * * *}$ & $0.811^{* * *}$ & - & 0.037 & $0.316^{*}$ & $0.400^{* *}$ & $0.474 * * *$ \\
\hline Hong Kong & $0.301 * * *$ & -0.017 & -0.049 & -0.024 & 0.190 & $0.344 * *$ & $0.286^{*}$ & $0.235^{*}$ & 0.137 & 0.171 & -0.222 & 0.132 & 0.218 & 0.220 & 0.071 & 0.096 & - & $0.431^{\text {**** }}$ & $0.544^{* * * *}$ & -0.096 \\
\hline Singapore & $0.290^{* * *}$ & 0.064 & 0.111 & 0.033 & $0.306^{* *}$ & $0.384 * * *$ & $0.400^{* * *}$ & $0.283^{* *}$ & 0.197 & $0.432^{* * *}$ & -0.004 & 0.267 & $0.402 * * *$ & $0.503^{* * * *}$ & 0.245 & 0.222 & $0.456^{* * *}$ & - & $0.701^{* * * *}$ & $0.299^{* *}$ \\
\hline Sydney & 0.145 & 0.160 & $0.264^{* *}$ & $0.298 * *$ & $0.283^{*}$ & $0.277^{*}$ & $0.330^{* *}$ & 0.142 & $0.308^{* *}$ & $0.453^{* * *}$ & $0.355^{* * *}$ & $0.480^{* * * *}$ & $0.397 * * *$ & $0.412^{* * *}$ & $0.449^{* * *}$ & $0.399^{* * *}$ & 0.086 & 0.236 & 0.029 & - \\
\hline
\end{tabular}

Notes: Table 5 reports the estimates of Rho based on the following OLS specification: $\frac{\mathrm{S}_{\mathrm{y}_{\mathrm{t}}}}{\sigma_{\mathrm{s}_{\mathrm{x}}} \sigma_{\mathrm{s}_{\mathrm{y}}}}=\hat{\alpha}+\hat{\rho}_{\mathrm{s}} \frac{\mathrm{S}_{\mathrm{x}_{\mathrm{t}}}}{\sigma_{\mathrm{s}_{\mathrm{x}}} \sigma_{\mathrm{s}_{\mathrm{y}}}}+\varepsilon_{\mathrm{t}}$

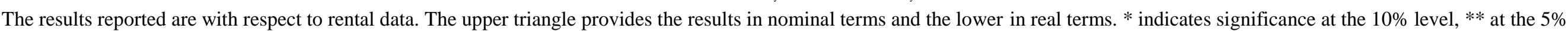
level and *** at the $1 \%$ level. 
Table 6: Concordance Indicator Capital Values

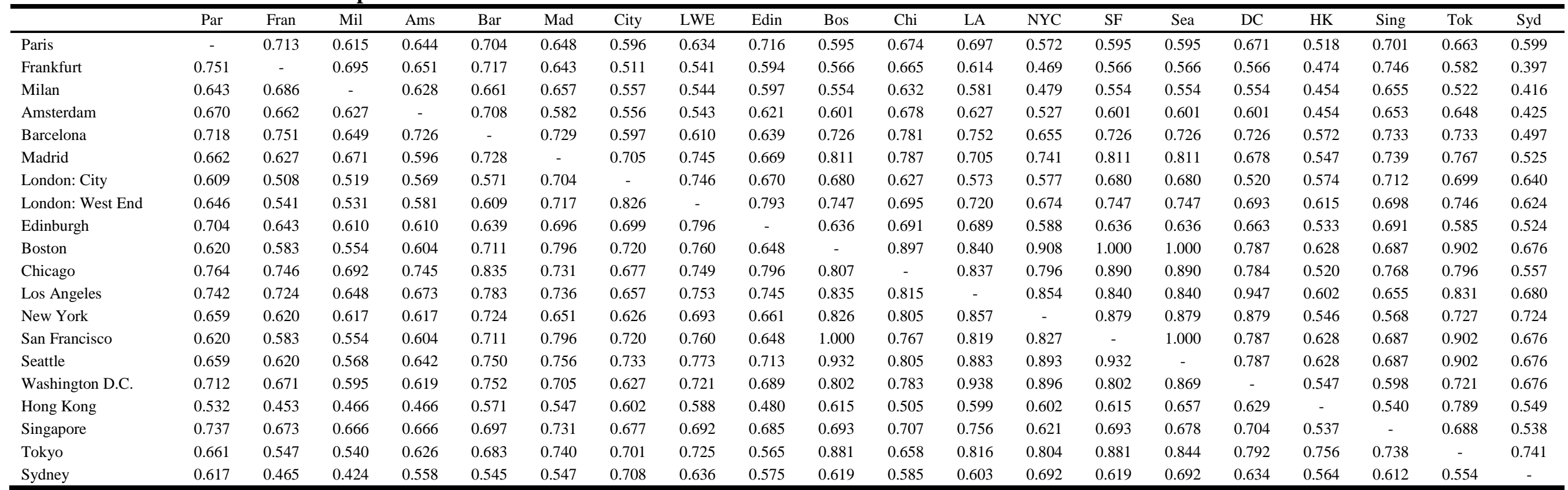

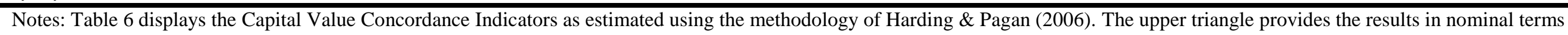
and the lower in real terms. The Concordance Indicator is estimated using the following formula: $\hat{\mathrm{I}}_{\mathrm{t}}=1+2 \hat{\rho}_{\mathrm{s}} \sigma_{\mathrm{s}_{\mathrm{x}}} \sigma_{\mathrm{s}_{\mathrm{y}}}+2 \mu_{\mathrm{s}_{\mathrm{x}}} \mu_{\mathrm{s}_{\mathrm{y}}}-\mu_{\mathrm{s}_{\mathrm{x}}}-\mu_{\mathrm{s}_{\mathrm{y}}}$ 
Table 7: Estimates of Rho with Capital Value Data

\begin{tabular}{|c|c|c|c|c|c|c|c|c|c|c|c|c|c|c|c|c|c|c|c|c|}
\hline & Par & Fran & Mil & Ams & Bar & $\mathrm{Mad}$ & City & LWE & Edin & Bos & Chi & LA & NYC & SF & Sea & DC & $\mathrm{HK}$ & Sing & Tok & Syd \\
\hline Paris & - & $0.317^{* * *}$ & 0.127 & $0.180^{*}$ & $0.359 * * *$ & $0.267^{* * *}$ & 0.173 & $0.261^{*}$ & $0.391 * * *$ & $0.221 *$ & $0.322 * * * *$ & $0.402 * * * *$ & $0.252^{* * *}$ & $0.221 *$ & $0.221^{*}$ & $0.382 * * *$ & 0.096 & $0.312 * * * *$ & $0.388 * * * *$ & $0.363^{* * * * *}$ \\
\hline Frankfurt & $0.421^{* * *}$ & - & $0.213^{*}$ & 0.053 & $0.365 * * *$ & $0.251^{* * *}$ & -0.043 & 0.054 & 0.067 & $0.214 * *$ & $0.305^{* * * *}$ & $0.256^{* * *}$ & 0.139 & $0.214 * *$ & $0.214 * *$ & $0.214 * *$ & 0.066 & $0.317^{* *}$ & $0.305 * *$ & 0.039 \\
\hline Milan & 0.190 & $0.218^{*}$ & - & 0.103 & $0.252^{* * *}$ & $0.283^{* * *}$ & 0.085 & 0.068 & 0.118 & 0.146 & $0.228 *$ & 0.158 & 0.074 & 0.146 & 0.146 & 0.146 & -0.027 & 0.169 & 0.102 & -0.021 \\
\hline Amsterdam & $0.253 * * *$ & 0.156 & 0.122 & - & $0.351 * * *$ & 0.111 & 0.080 & 0.064 & 0.162 & $0.257 * * *$ & $0.329 * * *$ & $0.263^{* *}$ & $0.206^{*}$ & $0.257 * * *$ & $0.257 * * *$ & $0.257^{* *}$ & -0.018 & 0.140 & $0.396^{* * * *}$ & 0.027 \\
\hline Barcelona & $0.384 * * *$ & $0.435^{* * * *}$ & $0.215^{*}$ & $0.389 * * *$ & - & $0.439 * * *$ & 0.178 & $0.211^{*}$ & $0.235^{*}$ & $0.486 * * *$ & $0.548 * * *$ & $0.511^{* * * *}$ & $0.410 * * *$ & $0.486 * * *$ & $0.486 * * *$ & $0.486 * * *$ & $0.196^{*}$ & $0.407 * *$ & $0.519^{* * * *}$ & 0.104 \\
\hline Madrid & $0.289 * *$ & $0.196^{*}$ & $0.302^{* * *}$ & 0.137 & $0.431^{* * *}$ & - & $0.403 * * *$ & $0.486 * * *$ & $0.316^{* * *}$ & $0.639 * * *$ & $0.564 * * *$ & $0.408^{* * * *}$ & $0.551 * * *$ & $0.639^{* * *}$ & $0.639^{* * *}$ & $0.371^{* * *}$ & 0.122 & $0.466^{* * * *}$ & $0.564 * * * *$ & 0.119 \\
\hline London: City & 0.207 & -0.021 & 0.014 & 0.121 & 0.129 & $0.404 * * *$ & - & $0.489 * * *$ & $0.329 * * *$ & $0.368 * * *$ & $0.245^{*}$ & 0.143 & 0.188 & $0.368 * * *$ & $0.368 * * *$ & 0.046 & 0.168 & $0.429 * * *$ & $0.414 * * *$ & $0.345^{* * * *}$ \\
\hline London: West End & $0.295 * *$ & 0.073 & 0.051 & 0.158 & $0.216^{* *}$ & $0.434 * * *$ & $0.652 * * * *$ & - & $0.588 * * *$ & $0.500 * * *$ & $0.385 * * *$ & $0.438^{* * * *}$ & $0.382 * * *$ & $0.500 * * *$ & $0.500 * * *$ & $0.393 * * *$ & $0.246 * *$ & $0.410^{* * * *}$ & $0.505 * * * *$ & $0.298 * *$ \\
\hline Edinburgh & $0.359^{* * * *}$ & $0.187^{*}$ & 0.138 & 0.138 & $0.223^{*}$ & $0.366^{* * * *}$ & $0.395^{* * * *}$ & $0.602 * * *$ & - & $0.296^{* * *}$ & $0.361^{* * * *}$ & $0.378 * * * *$ & $0.257^{*}$ & $0.296^{* *}$ & $0.296^{* *}$ & $0.350 * * *$ & 0.109 & $0.323^{* * *}$ & 0.206 & 0.152 \\
\hline Boston & $0.275^{* * *}$ & $0.236^{* *}$ & 0.146 & $0.254^{* *}$ & $0.461^{* * * *}$ & $0.614 * * *$ & $0.446 * * *$ & $0.525^{* * * *}$ & $0.325^{* * *}$ & - & $0.814^{* * * *}$ & $0.684 * * * *$ & $0.833^{* * * *}$ & $1.000^{* * * *}$ & $1.000^{* * * *}$ & $0.571 * * * *$ & 0.249 & $0.450^{* * * * *}$ & $0.805^{* * * *}$ & $0.354^{* * *}$ \\
\hline Chicago & $0.471^{* * * *}$ & $0.382^{* * * *}$ & $0.284 * *$ & $0.407^{* * * *}$ & $0.635^{* * *}$ & $0.434 * * *$ & $0.355^{* * * *}$ & $0.520^{* * * *}$ & $0.554^{* * * *}$ & $0.686^{* * * *}$ & - & $0.675^{* * * *}$ & $0.667^{* * * *}$ & $0.800^{* * * *}$ & $0.800^{* * *}$ & $0.586^{* * *}$ & 0.067 & $0.532^{* * * *}$ & $0.623^{* * * *}$ & 0.188 \\
\hline Los Angeles & $0.447 * * *$ & $0.396^{* * * *}$ & $0.231^{*}$ & $0.287 * * *$ & $0.537 * * *$ & $0.451^{* * * *}$ & $0.307^{* * *}$ & $0.510^{* * * *}$ & $0.460^{* * * *}$ & $0.705 * * *$ & $0.603^{* * * *}$ & - & $0.750^{* * * *}$ & $0.686^{* * * *}$ & $0.686^{* * * *}$ & $0.900^{* * * *}$ & 0.213 & $0.325 *$ & $0.674^{* * * *}$ & $0.408 * * *$ \\
\hline New York & $0.329^{* * *}$ & $0.273^{* *}$ & $0.248 * *$ & $0.248^{* *}$ & $0.463^{* * *}$ & $0.304 * *$ & $0.252^{*}$ & $0.386^{* * *}$ & $0.330^{* *}$ & $0.654^{* * *}$ & $0.649^{* * * *}$ & $0.730^{* * * *}$ & - & $0.771^{* * * *}$ & $0.771^{* * *}$ & $0.771 * * *$ & 0.046 & $0.302^{*}$ & $0.439 * *$ & $0.384^{* * *}$ \\
\hline San Francisco & $0.275^{* *}$ & $0.236^{* * *}$ & 0.146 & $0.254^{* *}$ & $0.461^{* * * *}$ & $0.614 * * *$ & $0.446 * * *$ & $0.525^{* * * *}$ & $0.325^{* * *}$ & $1.000^{* * * *}$ & $0.600^{* * * *}$ & $0.671 * * *$ & $0.657^{* * * *}$ & - & $1.000^{* * * *}$ & $0.571 * * *$ & 0.249 & $0.450^{* * * *}$ & $0.805^{* * * *}$ & $0.354 * *$ \\
\hline Seattle & $0.329^{* * *}$ & $0.273^{* *}$ & 0.142 & $0.302^{* * * *}$ & $0.516^{* * * *}$ & $0.518^{* * *}$ & $0.466 * * *$ & $0.546^{* * *}$ & $0.437^{* * * *}$ & $0.868 * * * *$ & $0.649^{* * * *}$ & $0.784 * * *$ & $0.787^{* * * *}$ & $0.868 * * *$ & - & $0.571 * * *$ & 0.249 & $0.450^{* * * *}$ & $0.805^{* * * *}$ & $0.354^{* * *}$ \\
\hline Washington D.C. & $0.409^{* * *}$ & $0.329^{* * *}$ & 0.156 & $0.210^{*}$ & $0.494^{* * * *}$ & $0.398 * * *$ & $0.249^{*}$ & $0.442^{* * * *}$ & $0.361^{* * *}$ & $0.617^{* * * *}$ & $0.565^{* * *}$ & $0.879^{* * *}$ & $0.797 * * *$ & $0.617 * * * *$ & $0.742^{* * * *}$ & - & 0.084 & 0.251 & $0.439 * *$ & $0.354^{* * *}$ \\
\hline Hong Kong & 0.133 & 0.011 & 0.011 & 0.011 & $0.211^{*}$ & 0.133 & $0.222^{*}$ & 0.189 & 0.011 & 0.222 & 0.089 & 0.256 & 0.211 & 0.222 & $0.322^{*}$ & $0.289 *$ & & 0.177 & $0.570^{* * * *}$ & 0.033 \\
\hline Singapore & $0.409^{* * *}$ & 0.199 & $0.223 * *$ & 0.223 & $0.328^{* *}$ & $0.434^{* * * *}$ & $0.355^{* * * *}$ & $0.397^{* * * *}$ & $0.309^{* *}$ & $0.441^{* * * *}$ & $0.326^{*}$ & $0.473^{* * * *}$ & 0.255 & $0.441^{* * * *}$ & $0.377^{* * *}$ & $0.395^{* *}$ & 0.159 & - & $0.487 * * * *$ & $0.301 * * *$ \\
\hline Sydney & $0.280 * * *$ & -0.021 & -0.124 & 0.169 & 0.125 & 0.113 & $0.426 * * *$ & $0.277^{* * *}$ & $0.183^{*}$ & 0.233 & $0.222^{*}$ & 0.236 & $0.388 * * *$ & 0.233 & $0.388 * *$ & $0.283^{*}$ & 0.110 & $0.280^{* *}$ & 0.091 & - \\
\hline
\end{tabular}

Notes: Table 6displays the estimates of Rho for capital values based on the following OLS specification: $\frac{\mathrm{S}_{\mathrm{y}_{\mathrm{t}}}}{\sigma_{\mathrm{s}_{\mathrm{x}}} \sigma_{\mathrm{s}_{\mathrm{y}}}}=\hat{\alpha}+\hat{\rho}_{\mathrm{s}} \frac{\mathrm{S}_{\mathrm{x}_{\mathrm{t}}}}{\sigma_{\mathrm{s}_{\mathrm{x}}} \sigma_{\mathrm{s}_{\mathrm{y}}}}+\varepsilon_{\mathrm{t}}$

The upper triangle provides the results in nominal terms and the lower in real terms. $*$ indicates significance at the $10 \%$ level, $* *$ at the $5 \%$ level and $* * *$ at the $1 \%$ level. 


\section{Endnotes}

${ }^{1}$ Please note that throughout the paper when we refer to investment we are considering capital investment in rental income producing standing investments. The paper does not consider investment in real estate development.

${ }^{2}$ The institutional investors were from the following markets:Germany, Japan, Netherlands, Sweden, UK and USA.

${ }^{3}$ Sirmans\&Worzala (2003) provide a review of those studies to have examined international real estate investment and portfolio diversification.

${ }^{4}$ See for example, Ziobrowski\&Curcio (1991), Ziobrowski\&Ziobrowski (1993) and Ziobrowski et al. (1997).

${ }^{5}$ See for example Brown \&Matysiak (2000) and Byrne \& Lee (2000).

${ }^{6}$ See also Derudder et al. (2003), Derudder\& Taylor (2005) and Taylor \&Aranya (2008) with respect to broader issues relating to connectivity.

${ }^{7}$ Lizieri (2009a) is an honourable exception in this regard and builds on a continuing stream of work to highlight the linkages between globalisation, financial services and the property markets. In addition, Friedman \& Wolff (1982) discuss the importance of a property infrastructure and its importance for global cities. Furthermore, they note that such markets may act as a destination for real estate investment.

${ }^{8}$ See, for example, studies such as Engle et al. (1994), Bekaert\& Harvey (1995), Richards (1995), Ammer\& Mei (1996), Bekaert et al. (2002, 2005, 2006).

${ }^{9}$ An initial concern with the European data was related to the use of quarterly data. For a number of quarters in the first half of the sample the figures with respect to some of the European markets had a zero change. This comes into consideration as the state variables define an expansion as a return greater than zero. As a robustness check, we ran all of the tests with an alternative definition. In this case an expansion was defined as a return equal to or greater than zero. The results do not differ substantially in terms of the significance reported. They are available on request from the authors.

${ }^{10}$ The data cited from the World Federation of Exchanges and the Securities Industry and Financial Markets Association was obtained from their respective websites (http://www.world-exchanges.org/ and www.sifma.org). 